\title{
High Molar Extinction Coefficient Ru(II)-Mixed Ligand Polypyridyl Complexes for Dye Sensitized Solar Cell Application
}

\author{
Malapaka Chandrasekharam, ${ }^{1}$ Ganugula Rajkumar, ${ }^{2}$ Chikkam Srinivasa Rao, ${ }^{1}$ \\ Thogiti Suresh, ${ }^{1}$ Yarasi Soujanya, ${ }^{3}$ and Paidi Yella Reddy ${ }^{2}$ \\ ${ }^{1}$ Inorganic and Physical Chemistry Division, Indian Institute of Chemical Technology, Uppal Road, Tarnaka, \\ Hyderabad 500 607, India \\ ${ }^{2}$ Aisin Cosmos Red Co. Ltd, Indian Institute of Chemical Technology, Uppal Road, Tarnaka, Hyderabad 500 607, India \\ ${ }^{3}$ Molecular Modelling Group, Indian Institute of Chemical Technology, Uppal Road, Tarnaka, Hyderabad 500 607, India \\ Correspondence should be addressed to Malapaka Chandrasekharam, csmalapaka@yahoo.com
}

Received 21 April 2011; Accepted 7 June 2011

Academic Editor: Surya Prakash Singh

Copyright ( 2011 Malapaka Chandrasekharam et al. This is an open access article distributed under the Creative Commons Attribution License, which permits unrestricted use, distribution, and reproduction in any medium, provided the original work is properly cited.

Two new ruthenium(II) mixed ligand terpyridine complexes, "Ru(Htcterpy) $(\mathrm{NCS})(\mathbf{L} 1)\left(\mathrm{N}\left(\mathrm{C}_{4} \mathrm{H}_{9}\right)_{4}\right)$, mLBD1" and Ru(Htcterpy) (NCS) $\left.(\mathbf{L} 2)\left(\mathrm{N}_{(} \mathrm{C}_{4} \mathrm{H}_{9}\right)_{4}\right)$, mLBD2 were synthesized and fully characterized by UV-Vis, emission, cyclic voltammogram, and other spectroscopic means, and the structures of the compounds are confirmed by ${ }^{1} \mathrm{H}-\mathrm{NMR}$, ESI-MASS, and FT-IR spectroscopes. The influence of the substitution of $\mathbf{L} 1$ and $\mathbf{L} 2$ on solar-to-electrical energy conversion efficiency $(\eta)$ of dye-sensitized solar cells (DSSCs) was evaluated relative to reference black dye. The dyes showed molar extinction coefficients of $17600 \mathrm{M}^{-1} \mathrm{~cm}^{-1}$ for mLBD1 and $21300 \mathrm{M}^{-1} \mathrm{~cm}^{-1}$ for mLBD2 both at $\lambda$ maximum of $512 \mathrm{~nm}$, while black dye has shown $8660 \mathrm{M}^{-1} \mathrm{~cm}^{-1}$ at $\lambda$ maximum of $615 \mathrm{~nm}$. The monochromatic incident photon-to-collected electron conversion efficiencies of $60.71 \%$ and $75.89 \%$ were obtained for mLBD1 and mLBD2 dyes, respectively. The energy conversion efficiencies of mLBD1 and mLBD2 dyes are $3.15 \%\left(J_{\mathrm{SC}}=11.86 \mathrm{~mA} / \mathrm{cm}^{2}, V_{\mathrm{OC}}=613 \mathrm{mV}, \mathrm{ff}=0.4337\right)$ and $3.36 \%\left(J_{\mathrm{SC}}=12.71 \mathrm{~mA} / \mathrm{cm}^{2}, V_{\mathrm{OC}}=655 \mathrm{mV}, \mathrm{ff}=0.4042\right)$, respectively, measured at the AM1.5G conditions, the reference black dye-sensitized solar cell, fabricated and evaluated under identical conditions exhibited $\eta$-value of $2.69 \%\left(J_{\text {SC }}=10.95 \mathrm{~mA} / \mathrm{cm}^{2}, V_{\mathrm{OC}}=655 \mathrm{mV}, \mathrm{ff}=0.3750\right)$.

\section{Introduction}

Among various photo voltaic technologies, dye-sensitized solar cells (DSSCs) are known to be less expensive, easy to fabricate and very efficient at varied incident angle of light. Therefore, intense attention has been devoted in the last two decades to the synthesis of new materials as sensitizers, metal oxide semiconductors, counter electrode materials, electrolytes, and so forth, for applications in high-performance and long durable DSSCs [1-6]. Especially sensitizer plays important role in the DSSCs device for obtaining highefficiency and long-term durability because of the possibility to chemically modify the sensitizer for better anchoring on $\mathrm{TiO}_{2}$, electron injection property and HOMO-LUMO tuning. To achieve this, many researchers around the world have been working either on modification of various reported sensitizers or designing new sensitizers. A variety of ruthenium(II) polypyridyl, terpyridyl and tetrapyridyl complexes, metal-free organic sensitizers, porphyrins, and phthalocyanines have been developed, since Graetzel introduced the first efficient nanocrystalline $\mathrm{TiO}_{2}$ solar cell sensitized with cis-bis(thiocyanato) bis(2,2' -bipyridyl-4,4' dicarboxylato) ruthenium(II) bis (tetrabutylammonium) (N719) [7-14]. Introduced in 1997, another ruthenium complex, black dye [tri(isothiocyanato)-2,2', $2^{\prime \prime}$-terpyridyl$4,4^{\prime}, 4^{\prime \prime}$-tricarboxylate ruthenium(II)] showed broad spectral absorption (ranging from 400 to $800 \mathrm{~nm}$ ) and achieved a record $10.4 \%$ (air mass 1.5) solar to power conversion efficiency in full sunlight $[15,16]$. However, the molar extinction coefficient of the sensitizer is relatively much lower as compared to the most efficient N719 dye. In addition, longterm durability is found to be one of the key limitations of 


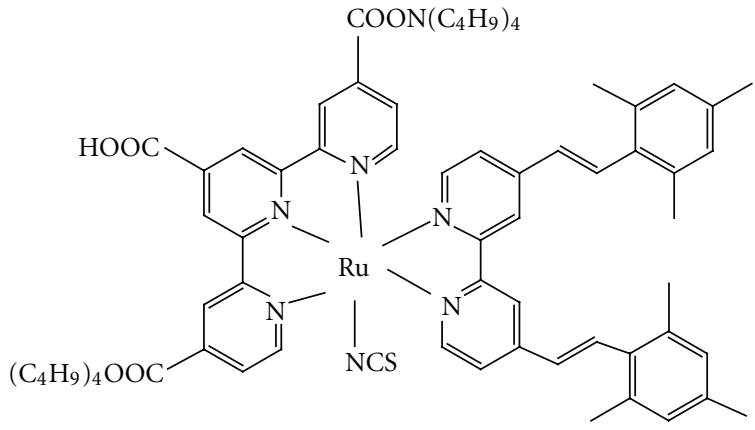

mLBD1

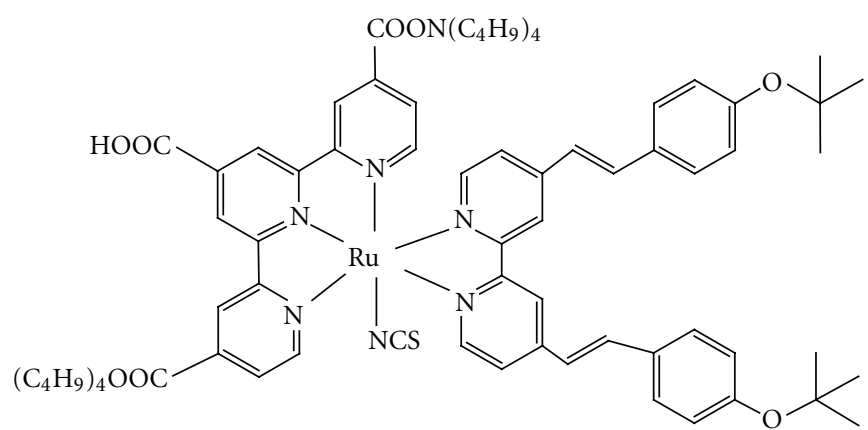

mLBD2

Figure 1: Structures of mLBD dyes.

the black dye-sensitized solar cell preventing them from their applicability in outdoor applications. The photodegradation of the dye anchored on $\mathrm{TiO}_{2}$ resulting from the interactions of the three NCS anions are proposed as the reasons for less stability. Sensitizers HRD2 [17] and K77 [18, 19] have been reported wherein 4,4'-bis(2,4,6-trimethylstyryl)2,2' -bipyridine (L1) and 4,4' -bis(4-tert-butoxystyryl)-2,2' bipyridine (L2) serve as ancillary ligands respectively, and substantially increased molar extinction coefficient $(\varepsilon)$ along with improved solar-to-electrical energy conversion efficiencies $(\eta)$ were obtained in DSSC devices. As a part of our ongoing program on synthesis of new materials and their photovoltaic performance evaluation in DSSC devices $[8,17,20-24]$, we envisaged that the design of new sensitizers with increased molar extinction coefficient, longterm durability, combined with broad absorption can be realized by substituting two thiocyanate anions of the black dye with electron donating conjugated bipyridine ligands. Thus, the terpyridine tricarboxylic acid strongly anchors on the semiconductor $\mathrm{TiO}_{2}$ surface, while the bipyridine ligands with strong electron donating groups bring about the unidirectional electron flow for efficient electron injection. With this new mixed ligand ruthenium complex concept, we report in this paper the synthesis and characterization of two new terpyridine and bipyridine-based ruthenium(II) complexes "Ru(Htcterpy)(NCS)(L1) $\left(\mathrm{N}_{(}\left(\mathrm{C}_{4} \mathrm{H}_{9}\right)_{4}\right), \mathrm{mLBD} 1$ " and $\mathrm{Ru}\left(\right.$ Htcterpy)(NCS) $(\mathbf{L} 2)\left(\mathrm{N}\left(\mathrm{C}_{4} \mathrm{H}_{9}\right)_{4}\right), \quad$ mLBD2, (Figure 1). Further the photovoltaic properties of test cell DSSCs constructed from these sensitizers and black dye are functionally evaluated and the influence of $\mathbf{L} 1$ and $\mathbf{L} 2$ on solar-to-electricity energy conversion efficiency $(\eta)$ were studied under similar fabrication and evaluation conditions.

\section{DSSC Device Fabrication}

The fluorine-doped $\mathrm{SnO}_{2}$ (FTO) conducting glass plates (Nippon Sheet Glass, $4 \mathrm{~mm}$ thick, $8 \Omega / \mathrm{sq}$ ) were cleaned with a detergent solution, rinsed with water and ethanol to remove organics or any other contaminants, and then dried. The glass plates were treated in a $\mathrm{UV}-\mathrm{O}_{3}$ system for 20 minutes and then laid a compact layer by treating the plates with $40 \mathrm{mM} \mathrm{TiCl}_{4}$ aqueous solution and heating at $70^{\circ} \mathrm{C}$ for
30 minutes to facilitate a good mechanical contact between the nanocrystalline $\mathrm{TiO}_{2}$ and the conducting FTO matrix. Over the glass plate, $9 \mu \mathrm{m}$ thickness D18T $\left(18 \mathrm{~nm} \mathrm{TiO}_{2}\right.$ particles) was laid as transparent layer and then a $4.8 \mu \mathrm{m}$ thickness HPW-400 (400 nm anatase $\mathrm{TiO}_{2}$ particles) was laid as scattering layer successively one over the other. The electrodes were coated with the $\mathrm{TiO}_{2}$ pastes, thus have an active area of $0.74 \mathrm{~cm}^{2}$, and were heated gradually under an air flow for 5 minutes each at $325^{\circ} \mathrm{C}$ and $375^{\circ} \mathrm{C}$ and for 15 minutes each at $450^{\circ} \mathrm{C}$ and $500^{\circ} \mathrm{C}$. The $\mathrm{TiO}_{2}$ electrodes were then allowed to cool and when the temperature attained to around $100^{\circ} \mathrm{C}$, immersed in dye solutions of ethanol and remained soaked for 16 hours under dark. After taking out from the dye solutions, the electrodes were rinsed with ethanol to remove the unadsorbed dye molecules and then dried under nitrogen gas. The counter electrodes were prepared by treatment of FTO glass plates (TEC 15, $2.2 \mathrm{~mm}$ thickness, Libbey-Owens-Ford Industries) with $\mathrm{TiCl}_{4}$ and further with a drop of $\mathrm{H}_{2} \mathrm{PtCl}_{6}$ solution (2 mg of Pt in $1 \mathrm{~mL}$ of ethanol) and heated at $430^{\circ} \mathrm{C}$ for 15 minutes. The dye sensitized $\mathrm{TiO}_{2}$ electrode and $\mathrm{Pt}$ counter electrode were assembled into a sealed sandwich type cell by heating with a hot-melt surlyn film (Surlyn 1702, $25 \mu \mathrm{m}$ thickness, Du-Pont) as a spacer inbetween the electrodes. The ionic liquid electrolyte was filled through the predrilled hole present on the counter electrode using vacuum filling technique, the hole was sealed with a Surlyn disk and a thin glass to avoid leakage of the electrolyte.

\section{Results and Discussion}

3.1. Synthesis. The synthesis of these complexes is achieved following Scheme 1. The oxidation of $4,4^{\prime} 4^{\prime \prime}$-triethyl-2, $2^{\prime}: 6^{\prime} 2^{\prime \prime}$-terpyridine to the tricarboxylic acid followed by esterification gives $4,4^{\prime}, 4^{\prime \prime}$-trimethoxycarbonyl-2,2' $: 6^{\prime} 2^{\prime \prime}$-terpyridine. The bipyridyl ligands $\mathbf{L} 1$ and $\mathbf{L} 2$ were synthesized by condensing 2,4,6-trimethylbenzaldehyde or 4-tertbutoxybenzaldehyde with tetraethyl 2,2'-bipyridine-4,4'diylbis(methylene)diphosphonate under Wittig conditions. The reaction of ruthenium trichloride with the triester in presence of $\mathrm{EtOH} / \mathrm{CHCl}_{3}$ under reflux for $4 \mathrm{hrs}$ results in the trichloro $\mathrm{Ru}$-complex. The complex is further refluxed for $4 \mathrm{hrs}$ in DMF in presence of bipyridyl ligand (L1 or L2) 
<smiles>CC#CCCc1ccnc(-c2cc(CC)cc(-c3cc(CC)ccn3)n2)c1</smiles><smiles>CC(=O)c1cc(C(=O)O)cc(-c2cc(C(=O)O)cc(-c3cc(C(=O)O)cc(-c4cc(C(=O)O)cc(-c5cc(C(=O)O)ccn5)n4)n3)n2)n1</smiles><smiles>CC(=O)c1ccnc(-c2cc(C(C)=O)cc(-c3cc(C(C)=O)cc(C(C)(Cl)Cl)n3)n2)c1</smiles><smiles>[R]c1ccnc(-c2cc([R])ccn2)c1</smiles>

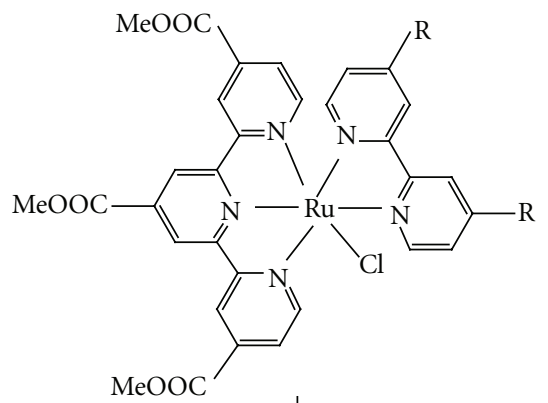<smiles>CC#CC=Cc1cc(C)cc(C)c1C=CCC</smiles><smiles>CC(C)=Cc1ccc(OC(C)(C)C)cc1</smiles>

Scheme 1: Synthesis route of mLBD dyes; (i) $\mathrm{K}_{2} \mathrm{Cr}_{2} \mathrm{O}_{7}, \mathrm{H}_{2} \mathrm{SO}_{4} / \mathrm{H}_{2} \mathrm{O}, 80^{\circ} \mathrm{C}$, 10 hours; (ii) $\mathrm{MeOH}$, conc. $\mathrm{H}_{2} \mathrm{SO}_{4}$, reflux, 6 hours (iii) $\mathrm{RuCl}_{3}$, $\mathrm{EtOH} / \mathrm{CHCl}_{3}$, reflux under dark, 4 hours; (iv) L1 or L2, DMF reflux, 4 hours; (v) $\mathrm{NH}_{4} \mathrm{NCS}$, reflux, 2 hours, TEA, water, reflux, 48 hours.

followed by addition of excess $\mathrm{NH}_{4} \mathrm{NCS}$, under refluxing conditions in DMF. The triester mixed ligand complex is finally treated with TEA in water under refluxing conditions for $48 \mathrm{hrs}$ resulted in the formation of mLBD1 and mLBD2 complexes. The crude complexes obtained were purified on Sephadex LH20 column chromatography to afford mLBD1 and mLBD2 sensitizers as pure compounds. The new sensitizers were fully characterized by UV-Vis, emission, cyclic voltammogram, and other spectroscopic means, and the structures of the compounds are confirmed by ${ }^{1} \mathrm{HNMR}$, ESIMASS, FT-IR spectroscopes.

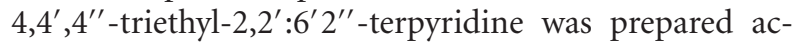
cording to reported procedure ref. Tetrabutylammoniumhydroxide, 2, 4, 6-trimethylbenzaldehyde or 4-tert-butoxybenzaldehyde, ammonium thiocyanate, sodiumhydride, and ruthenium trichloride were purchased from Sigma-Aldrich. 
All solvents and reagents, unless otherwise stated, were of Laboratory Reagent Grade and used as received. The tetraethyl 2,2' -bipyridine-4,4' -diylbis(methylene)diphosphonate was prepared in accordance to the reported procedure. Sephadex LH-20 was procured from GE Healthcare BioSciences AB, SE-75184, Uppsala and was used to purify the crude complexes on column chromatography. Brucker 300Avance ${ }^{1} \mathrm{H}$-NMR spectrometer run at $500 \mathrm{MHz}$ was employed to record the ${ }^{1} \mathrm{H}-\mathrm{NMR}$ spectrum. Shimadzu LCMS2010EV model with ESI probe was employed for MASS analysis. Shimadzu UV-Vis spectrometer (model 1700) and Fluorolog 3, J. Y. Horiba Fluorescence spectrometer were employed to record the electronic absorption and emission spectra.

Synthesis of 4,4' $4^{\prime \prime}$-Tricarboxy-2,2' $: 6^{\prime} 2^{\prime \prime}$-Terpyridine (1). 4, $4^{\prime}, 4^{\prime \prime}$-triethyl-2,2' $: 6^{\prime} 2^{\prime \prime}$-terpyridine $(10 \mathrm{~g}, 31.55 \mathrm{mmol})$ was added to a mixture of Conc. $\mathrm{H}_{2} \mathrm{SO}_{4}$ and water $(150 \mathrm{~mL}+$ $150 \mathrm{~mL}$ ), and dissolved at room temperature. To this solution, $\mathrm{K}_{2} \mathrm{Cr}_{2} \mathrm{O}_{7}(62.1 \mathrm{~g}, 211.4 \mathrm{mmol})$ was added in portions for about 4 hours (note: while adding $\mathrm{K}_{2} \mathrm{Cr}_{2} \mathrm{O}_{7}$, vigorous exothermic reaction takes place, cooling is necessary to avoid the reaction temperature to exceed $50^{\circ} \mathrm{C}$ ). The cooling bath was removed, and the reaction flask was heated to $80^{\circ} \mathrm{C}$ using heating mantle for 6 hours with stirring. After allowing it to cool to room temperature, the reaction mixture was poured into ice water $(1200 \mathrm{~mL})$. After keeping it for 4 hours at $0^{\circ} \mathrm{C}$, suspension was filtered by suction. The separated greenish-yellow precipitate was washed thoroughly with distilled water (until the filtrate is colorless) and dried under vacuum. The pale yellow solid was suspended in aqueous $\mathrm{HNO}_{3}(18 \mathrm{~mL}$ of $70 \%)$ and refluxed for 3 hours. After cooling to room temperature, the reaction mixture was poured into ice water $(1000 \mathrm{~mL})$ and stored at $0^{\circ} \mathrm{C}$ over night. The resulted white solid was collected on a sintered glass crucible (G4), washed thoroughly with water until the filtrate is colorless, and dried under vacuum to give $4,4^{\prime} 4^{\prime \prime}$ tricarboxy-2,2': $6^{\prime} 2^{\prime \prime}$-terpyridine acid, which was characterized by ${ }^{1} \mathrm{H}-\mathrm{NMR}$ spectroscopy. ${ }^{1} \mathrm{H}-\mathrm{NMR}\left(\mathrm{D}_{2} \mathrm{O} / \mathrm{NaOD}\right)$ ppm: $7.72(2 \mathrm{H}, \mathrm{dd}), 8.22(2 \mathrm{H}, \mathrm{s})$, and $8.62(2 \mathrm{H}, \mathrm{d}), 8.82(2 \mathrm{H}$, d). Chemical formula ESIMS: $\mathrm{C}_{18} \mathrm{H}_{11} \mathrm{~N}_{3} \mathrm{O}_{6}(\mathrm{M}+\mathrm{H})^{+}: 365$ $(100 \%)$.

Synthesis of $4,4^{\prime}, 4^{\prime \prime}$-Trimethoxycarbonyl-2,2': $6^{\prime} 2^{\prime \prime}$-Terpyridine (2). To a suspension of $4,4^{\prime} 4^{\prime \prime}$-tricarboxy-2,2': $6^{\prime} 2^{\prime \prime}$-terpyridine $(20.0 \mathrm{~g}, 5.49 \mathrm{mmol})$ in absolute methanol $(850 \mathrm{~mL})$ was added conc. sulfuric acid $(115 \mathrm{~mL})$. The mixture was refluxed for 6 hours to obtain a clear solution and then cooled to room temperature. Water $(400 \mathrm{~mL})$ was added and the excess methanol removed under vacuum. The $\mathrm{pH}$ was adjusted to neutral with $\mathrm{NaOH}$ solution, and the resulting precipitate was filtered and washed with water $(\mathrm{pH}=7.0)$. The solid was dried to obtain $17.0 \mathrm{~g}$ of desired compound. ${ }^{1} \mathrm{H}-\mathrm{NMR}\left(300 \mathrm{MHz} \mathrm{CDCl}_{3}, \delta\right): 3.95\left(3 \mathrm{H}, \mathrm{s}, \mathrm{CH}_{3}\right) ; 4.05(6 \mathrm{H}$, $\left.\mathrm{s}, \mathrm{CH}_{3}\right) ; 7.98\left(2 \mathrm{H}, \mathrm{d}, J=6 \mathrm{~Hz}\right.$, aryl $\mathrm{H}$ on $\mathrm{C} 5$ and $\left.\mathrm{C}^{\prime}\right)$; $8.88\left(2 \mathrm{H}, \mathrm{d}, J=6 \mathrm{~Hz}\right.$, aryl $\mathrm{H}$ on $\mathrm{C} 6$ and $\left.\mathrm{C}^{\prime}\right) ; 9.00(2 \mathrm{H}$, $\mathrm{s}$, aryl $\mathrm{H}$ on $\mathrm{C} 3$ and $\left.\mathrm{C}^{\prime}\right) ; 9.20(2 \mathrm{H}, \mathrm{d}, J=6 \mathrm{~Hz})$ ESIMS: $\left(\mathrm{C}_{21} \mathrm{H}_{17} \mathrm{~N}_{3} \mathrm{O}_{6}\right)(\mathrm{M}+\mathrm{H})^{+}: 408(100 \%)$.
Synthesis of Ruthenium Trichloro Complex (3). Ruthenium tri chloride $(642 \mathrm{mg}, 2.5 \mathrm{mmol})$ was dissolved in a mixture of ethanol and chloroform $(100 \mathrm{~mL})$. To this, $4,4^{\prime}, 4^{\prime \prime}$-trimethoxycarbonyl-2,2': $6^{\prime} 2^{\prime \prime}$-terpyridine $(1.0 \mathrm{~g}, 2.5 \mathrm{mmol})$ was added, and then, the reaction mixture was refluxed for 4 hours under nitrogen atmosphere in the absence of light. The progress of the reaction was monitored by UV-VIS spec-troscopy. After completion of 3 hours, the solution was concentrated on rotary evaporator. The crude trichloro compound washed with ethanol and dried under vacuum to obtain white solid (85\% yield) ${ }^{1} \mathrm{H}-\mathrm{NMR}\left(\mathrm{D}_{2} \mathrm{O} / \mathrm{NaOD}\right)$ ppm: 8.70 $(\mathrm{d}, 2 \mathrm{H}), 8.22(\mathrm{~s}, 2 \mathrm{H}), 8.10(\mathrm{~s}, 2 \mathrm{H}), 7.62$ (2H, d). ESIMS: $\left(\mathrm{C}_{21} \mathrm{H}_{17} \mathrm{Cl}_{3} \mathrm{~N}_{3} \mathrm{O}_{6} \mathrm{Ru}\right)(\mathrm{M}+\mathrm{H})^{+}: 615(25 \%)$.

Synthesis of L1 and L2 (Representative Procedure). Sodium hydride (177 mg, $7.38 \mathrm{mmol}$ ) was washed with dry hexane $(3 \times 10 \mathrm{~mL})$. To this suspension, a THF solution of tetraethyl $2,2^{\prime}$-bipyridine- $4,4^{\prime}$-diylbis(methylene)diphosphonate derivative $(560 \mathrm{mg}, 1.23 \mathrm{mmol}$ ) was added, and the resulting mixture was stirred at room temperature for a period of 30 minutes. To this, 2,4,6-trimethyl benzaldehyde (546 mg, $3.69 \mathrm{mmol}$ dissolved in THF) or 4-tert-butoxy benzaldehyde (656 mg, $3.69 \mathrm{mmol}$ dissolved in THF) was added dropwise at room temperature while stirring. The reaction mixture was refluxed for 12 hours and then allowed to cool to room temperature. The reaction mixture was filtered through a short plug of silica gel using diethyl ether. The filtrate was concentrated, and methanol was added. The corresponding bipyridyl ligand was precipitated and the precipitate was filtered and washed with cool methanol. The solid was dried to obtain pure $\mathbf{L} 1$ or $\mathbf{L} 2$.

4, 4'-Bis-[2-(2,4,6-Trimethyl-Phenyl)-Vinyl]-[2, 2']-Bipyridine (L1). ${ }^{1} \mathrm{H}-\mathrm{NMR}\left(300 \mathrm{MHz}, 25^{\circ} \mathrm{C}, \mathrm{CDCl}_{3}\right) 2.35(\mathrm{~s}, 18 \mathrm{H})$, $6.58(\mathrm{~d}, 1 \mathrm{H}), 6.62(\mathrm{~s}, 4 \mathrm{H}), 7.25(\mathrm{~s}, 2 \mathrm{H}), 7.31(\mathrm{~d}, 1 \mathrm{H}), 8.63$ $(\mathrm{d}, 2 \mathrm{H}), 8.71(\mathrm{~d}, 2 \mathrm{H})$; ESI-MS: $\left(\mathrm{C}_{32} \mathrm{H}_{32} \mathrm{~N}_{2}\right)(\mathrm{M}+\mathrm{H})^{+}: 444$ (100\%).

4, 4'-Bis-[2-(2-(Tert-Butoxy Phenyl)-Vinyl)]-[2, 2']-Bipyridine (L2). ${ }^{1} \mathrm{H}-\mathrm{NMR}\left(200 \mathrm{MHz}, 25^{\circ} \mathrm{C}, \mathrm{CDCl}_{3}\right) d$ [ppm]: 8.67 $(\mathrm{d}, 2 \mathrm{H}), 8.54(\mathrm{~s}, 1 \mathrm{H}), 7.46(\mathrm{~m}, 8 \mathrm{H}), 7.06(\mathrm{~m}, 6 \mathrm{H}), 1.40(\mathrm{~s}$, $18 \mathrm{H})$. Chemical formula $\left(\mathrm{C}_{34} \mathrm{H}_{36} \mathrm{~N}_{2} \mathrm{O}_{2}\right)$, ESI-MS: Calcd for $(\mathrm{M}+\mathrm{H})^{+}$: $504(55 \%)$.

Synthesis of $m$ LBD Complex (Representative Procedure). Dry DMF $(100 \mathrm{~mL})$ was placed into $250 \mathrm{~mL}$ RB flask, to which ruthenium trichloro complex $(200 \mathrm{mg}, 0.32 \mathrm{mmol})$ was added under nitrogen atmosphere, the resulting solution was stirred for five minutes, and then, $\mathbf{L} 1$ or $\mathbf{L} 2(0.391 \mathrm{mmol})$ was added. The reaction mixture was refluxed for 4 hours under $\mathrm{N}_{2}$ atmosphere. After completion of 4 hours, the mixture was cooled to $80^{\circ} \mathrm{C}$, and then, aqueous solution of ammonium thiocyanate $(768 \mathrm{mg}$ in $2 \mathrm{~mL}$ of water) was added. The mixture was further refluxed for 2 hours. The progress of the reaction was monitored by UV-VIS spectroscopy. After 2 hours, the reaction mixture was cooled to room temperature, and triethylamine was added followed by water $(2 \mathrm{~mL}+$ $2 \mathrm{~mL}$ ). The mixture was further refluxed for 48 hours. Then, 


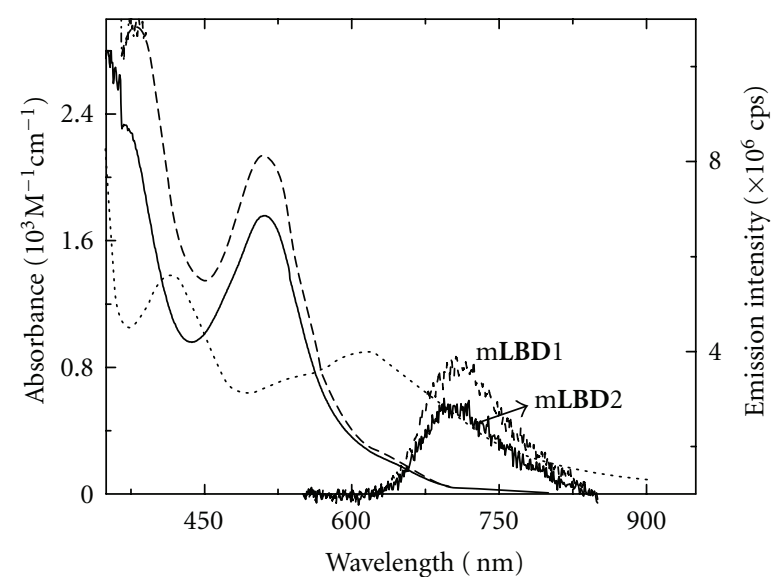

FIgURE 2: Equimolar absorption spectra of mLBD1 (-), mLBD2 (--) and black dye (...) in ethanol and emission spectra of mLBD1and mLBD2.

the solvent was removed on rotary evaporator, and water was added to get the precipitate. The solid was filtered, washed with water and dried under vacuum. The crude compound was dissolved in $\mathrm{MeOH}$ and methanolic TBA and purified on Sephadex LH-20 column chromatography eluting with $\mathrm{MeOH}$. The main band was collected and concentrated. This purification procedure was repeated 3-4 times to afford mLBD 1 and mLBD2 dyes in the pure form.

mLBD1. ${ }^{1} \mathrm{H}-\mathrm{NMR}\left(300 \mathrm{MHz}, \mathrm{CD}_{3} \mathrm{OD}+\mathrm{CDCl}_{3}, \delta_{\mathrm{H}}\right): 9.50$ $(\mathrm{d}, 1 \mathrm{H}), 8.95(\mathrm{~s}, 2 \mathrm{H}), 8.88(\mathrm{~d}, 1 \mathrm{H}), 8.75(\mathrm{~s}, 2 \mathrm{H}), 8.60(\mathrm{~s}$, $1 \mathrm{H}), 8.05(\mathrm{~d}, 1 \mathrm{H}), 7.85(\mathrm{~d}, 2 \mathrm{H}), 7.75(\mathrm{~m}, 4 \mathrm{H}), 7.40(\mathrm{~d}$, $2 \mathrm{H}), \quad 7.10(\mathrm{~d}, 1 \mathrm{H}), 6.90(\mathrm{~s}, 1 \mathrm{H}), 6.85(\mathrm{~s}, \quad 2 \mathrm{H}), \quad 6.75$ $(\mathrm{s}, 2 \mathrm{H}), 6.40(\mathrm{~d}, 1 \mathrm{H}), 3.50-0.86(\mathrm{~m}, 90 \mathrm{H})$; ESI-MASS: $\mathrm{RuC}_{51} \mathrm{H}_{43} \mathrm{~N}_{6} \mathrm{O}_{6} \mathrm{~S}(1 \mathrm{TBA})(\mathrm{M}+)=1211(35 \%)$. IR $(\mathrm{KBr}): v=$ $2965 \mathrm{~cm}^{-1}\left(\mathrm{CH}_{3}\right), 2095(\mathrm{NCS}), 1605\left(\mathrm{COO}_{\mathrm{asym}}^{-}\right), 1529(\mathrm{BPy})$, 1474(BPy), 1354 ( $\left.\mathrm{COO}_{\text {sym }}^{-}\right)$.

mLBD2. ${ }^{1} \mathrm{H}-\mathrm{NMR}\left(300 \mathrm{MHz}, \mathrm{CD}_{3} \mathrm{OD}+\mathrm{CDCl}_{3}, \delta_{\mathrm{H}}\right): 9.65$ $(\mathrm{d}, 1 \mathrm{H}), 9.10(\mathrm{~s}, 2 \mathrm{H}), 9.00(\mathrm{~s}, 1 \mathrm{H}), 8.90(\mathrm{~s}, 2 \mathrm{H}), 8.70$ $(\mathrm{s}, 1 \mathrm{H}), 8.20(\mathrm{~d}, 1 \mathrm{H}), 7.85(\mathrm{~d}, 2 \mathrm{H}), 7.75-7.38(\mathrm{~m}, 10 \mathrm{H})$, 7.25-6.75 (m, 6H), 3.50-0.86 (m, 90H). ESI-MASS: $\mathrm{RuC}_{53} \mathrm{H}_{47} \mathrm{~N}_{6} \mathrm{O}_{8} \mathrm{~S}(1 \mathrm{TBA})(\mathrm{M}+1)=1272(80 \%)$. IR (KBr): $v=2965 \mathrm{~cm}^{-1}$ ( $t$-butyl), 2095(NCS), 1605(COO asym $\left.^{-}\right), 1529$ (BPy), 1474(BPy), 1354( $\left.\mathrm{COO}_{\text {sym }}^{-}\right)$.

3.2. Absorption, Emission, and Electrochemical Properties. To have a preliminary evaluation of the light harvesting capacity of the new sensitizers, the electronic absorption spectra were recorded in ethanol and compared with that of black dye. As compared to black dye, these new sensitizers show intense UV absorption band at around $380 \mathrm{~nm}$, which are assigned to the ligand centred $\pi-\pi^{*}$ transition of the H3tctpy ligand [25, 26] and other intense low-energy absorption band at around $510 \mathrm{~nm}$. The low-energy absorption band is assigned to metal-to-ligand charge-transfer (MLCT) transition. Absorption spectra of these dyes are very different from that of black-dye, which exhibit intense and broad absorption bands at about 430 and $520 \mathrm{~nm}$ and a distinct shoulder low-energy absorption band at around $700 \mathrm{~nm}$ extending up to $850 \mathrm{~nm}$ (Figure 2). As compared to black dye, the low-energy absorption bands of mLBD dyes are blue-shifted. The dyes showed molar extinction coefficients of $17600 \mathrm{M}^{-1} \mathrm{~cm}^{-1}$ for mLBD1 and $21300 \mathrm{M}^{-1} \mathrm{~cm}^{-1}$ for mLBD2 both at $\lambda$ maximum of $512 \mathrm{~nm}$, while black dye has shown $8660 \mathrm{M}^{-1} \mathrm{~cm}^{-1}$ at $\lambda$ maximum of $615 \mathrm{~nm}$. The $\mathrm{mLBD}$ dyes increased the lightharvesting ability of the new sensitizers by enhancing their molar extinction coefficients by around 50\%, especially in the wavelength region of $400-550 \mathrm{~nm}$, which could be the contribution of extended $\pi$-conjugation of these bipyridyl ligands $\mathbf{L} 1$ and $\mathbf{L} 2$.

In case of mLBD dyes, the increased molar extinction coefficient is expected due to extension of $\pi$-conjugation, which is akin to the molecular cosensitization for efficient panchromatic DSSC sensitisers [27]. What is expected of these dyes is maintaining the absorption spectrum of blackdye, while enhancing the molar extinction coefficient. But the introduction of these bipyridyl ligands shifted the absorption spectrum towards blue region. To understand the molar extinction coefficient's augment and the blue-shifted absorption spectrum, time-dependent density functional theory calculations were run based on DFT optimized structure in ethanol medium. The conductor-like polarizable continuum model (C-PCM), which accounts for the effects of the solvent molecule ethanol was used along with the calculations. In mLBD dyes, the replacement of two thiocyanato anions by a single chelating $\pi$-conjugated bipyridine ligand stabilizes the ground state with less electron donation to the centre ruthenium(II), and this causes a decrease in the overall energy of the $2 \mathrm{~g}$ metal orbitals. For these complexes, the lowenergy MLCT transition bands from this orbital to LUMO exhibit significant blue shift [28].

Besides the molar extinction coefficient, the photovoltaic performance of DSSC is also influenced by quantity of absorbed dye and its pattern over $\mathrm{TiO}_{2}$ surface, which is further dependent on the size and geometrical structure of photosensitizer. To investigate further, the absorption measurements over $\mathrm{TiO}_{2}$ films were carried out by staining $7 \mu \mathrm{m}$ thick $\mathrm{TiO}_{2}$ electrodes in $0.3 \mathrm{mM}$ dye solutions prepared in ethanol for 16 hours under the dark. After that the electrodes were washed with ethanol to remove unadsorbed dye molecules and dried under nitrogen purging. The absorptions recorded using UV-Vis spectrometer showed relatively decreased film absorptions as compared with that of black dye. The substitution of two NCS anions by 4,4' -bis(2,4,6-trimethylstyryl)$2,2^{\prime}$-bipyridine and 4,4' -bis(4-tert-butoxystyryl)-2,2' -bipyridine in the black dye increased the molecular size by more than one and half times, and additionally, this influenced the packing densities of these molecules on $\mathrm{TiO}_{2}$ films.

Prior to fabrication of DSSCs devices, cyclic voltammetry measurements of the sensitizers were conducted to ensure that the LUMOs of these complexes are suitable for injecting electrons into the conduction band of $\mathrm{TiO}_{2}$ and also whether their HOMOs match the energy level of the $\mathrm{I}_{2} / \mathrm{I}_{3}{ }^{-}$redox couple. The cyclic voltammogram of these dyes were measured using tetrabutyl ammonium perchlorate $(0.1 \mathrm{M}$ in acetonitrile) as an electrolyte and ferrocene as an internal standard 


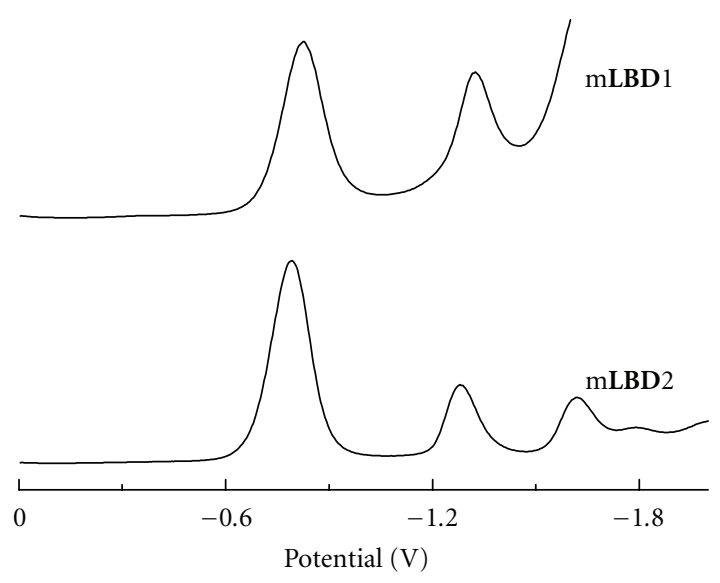

FIgure 3: Differential pulse voltammograms of mLBD dyes, supporting electrolyte is $0.1 \mathrm{M}$ tetrabutylammonium perchlorate in acetonitrile.

at $0.42 \mathrm{~V}$ versus SCE. Figure 3 shows the voltammogram of $\mathrm{mLBD}$ dyes in acetonitrile. Reversible redox were observed for these mLBD dyes, and similar to other ruthenium(II) pyridyl complexes, the measured oxidation potentials are 0.8611 and $0.8280 \mathrm{~V}$, while the reduction potentials are -0.8266 and $-0.7894 \mathrm{~V}$ versus SCE for mLBD1 and mLBD2 dyes, respectively. The more positive potentials of these sensitizers, relative to $\mathrm{I}^{-} / \mathrm{I}_{3}{ }^{-}$redox couple $(0.24 \mathrm{~V}$ versus SCE) in the electrolyte, provide a large thermodynamic driving force for the regeneration of the dyes by iodide. Based on the absorption and emission spectra of these complexes, the excitation transition energies $\left(E_{0-0}\right)$ are estimated to be 1.9096 and $1.8892 \mathrm{eV}$ for $\mathrm{mLBD} 1$ and mLBD2 dyes, respectively (obtained by converting the wavelengths of $650 \mathrm{~nm}$ for mLBD 1 and $657 \mathrm{~nm}$ for mLBD2, at which their individual absorption and emission spectra (Figure 2(b)) intersect, into electron volts). The standard potentials $\left(\phi^{0}\left(S^{+} / S^{*}\right)\right)$ calculated from the relation of $\left[\phi^{0}\left(S^{+} / S\right)=\phi^{0}\left(S^{+} / S^{*}\right)-E_{0-0}\right]$ are -1.0485 and $-1.0612 \mathrm{~V}$ versus SCE for mLBD1 and mLBD2, respectively. So, $\phi^{0}\left(S^{+} / S^{*}\right)$ values are more negative (or higher in energy) than the conduction band edge of $\mathrm{TiO}_{2}(-0.8 \mathrm{~V}$ versus SCE) providing ample thermodynamic driving force to inject electrons from the dye to $\mathrm{TiO}_{2}$.

3.3. Computational Studies. In order to gain insight, the electronic ground states of fully protonated mLBD dyes were optimized in gaseous phase by using the density functional theory (DFT) with MPW1PW91 method and lanl2dz basis set for ruthenium and 6-31G(d) for $\mathrm{H}, \mathrm{C}, \mathrm{N}, \mathrm{O}, \mathrm{S}$ atoms as implemented in Gaussian $09 \mathrm{~W}$ and Gaussian View 5 interface software. The unoccupied and occupied frontier molecular orbitals of mLBD dyes are depicted in Figures 4 and 5 with isodensity surface values fixed at 0.04 . The LUMO is mainly ascribed to the H3tctpy ligand with a considerable amount of $\mathrm{p}$ back-donation from the $\mathrm{t} 2 \mathrm{~g}$ orbitals. Moreover, the carboxylic groups show sizable contributions to LUMO and facilitate the electron injection from the excited mLBD dyes to the $\mathrm{TiO}_{2}$ conduction band. Similar to other ruthenium(II) sensitizers, the HOMO has electron density distribution mainly located on the metal centre and NCS anions. TD DFT calculations showed the highly allowed transition from $\mathrm{HOMO}-2 / \mathrm{HOMO}-3$ to $\mathrm{LUMO}+2$ orbital, in which the electron densities of HOMO-2 and HOMO-3 are located at the metal centre, NCS ligand and the chelating $\mathbf{L} 1$ or $\mathbf{L} 2$ bipyridine, whereas that of $\mathrm{LUMO}+2$ orbital is contributed to mainly by $\mathbf{L} 1$ or $\mathbf{L} 2$ bipyridine moieties. The HOMO/LUMO band gaps predicted through the DFT optimization are 2.035 and $2.045 \mathrm{eV}$ for $\mathrm{mLBD} 1$ and mLBD2, respectively, while the band gap for parental blackdye optimized under similar conditions is $1.89 \mathrm{eV}$.

3.4. Thermal Stability. The incorporation of the ancillary bipyridine ligands into the parental black dye make the dye more hydrophobic and one of the advantages of these mixed ligand dyes could be their stability obtained by the replacement of NCS anions by stable panchromatic chelating ancillary bipyridine ligand [29]. One of the desirable parameters to retain the initial photovoltaic performance of the DSSC is the high thermal stability of the ruthenium(II) sensitizer [30], and hence, the TGA analysis of the sensitizers was performed using a TGA/SDTA $851^{\mathrm{e}}$ thermal system (Mettler Toledo, Switzerland) at heating rate of $10^{\circ} \mathrm{C} / \mathrm{min}$ in the temperature range of $25^{\circ} \mathrm{C}-600^{\circ} \mathrm{C}$ under $\mathrm{N}_{2}$ atmosphere (flow rate of $30 \mathrm{~mL} / \mathrm{min}$ ). Film samples ranging from 8 to $10 \mathrm{mg}$ were placed in the sample pan and heated, while weight losses are recorded against temperature difference. The thermograms of mLBD dyes are shown in Figure 6, in which the derivative of $\%$ conversion plotted against to temperature. The thermograms show a very good thermal stability $\left(310^{\circ} \mathrm{C}\right.$ for $\mathrm{mLBD} 1$ and $350^{\circ} \mathrm{C}$ for $\left.\mathrm{mLBD} 2\right)$, while under comparable conditions the black dye showed $290^{\circ} \mathrm{C}$.

3.5. Photovoltaic Properties. To evaluate the influence of 4 , $4^{\prime}$-bis(2,4,6-trimethylstyryl)-2,2' -bipyridine and 4,4' -bis(4tert-butoxystyryl)-2,2' -bipyridine on the photovoltaic performance, a high-quality double-layer titania films $(9+$ $4.8 \mu \mathrm{m}$ ) were employed to fabricate $0.74 \mathrm{~cm}^{2}$ active area DSSC cells in combination with a high durable electrolyte, Z580, containing $0.2 \mathrm{M} \mathrm{I}_{2}, 0.5 \mathrm{M}$ guanidinium thiocyanate and $0.5 \mathrm{M} \mathrm{N}$-methylbenzimidazole in a mixture of 1-propyl3-methylimidazolium iodide/1-ethyl-3-methyl imdazoliumtetracyanoborate $(65 / 35, \mathrm{v} / \mathrm{v})$. Photon-to-current conversion efficiency spectrum was recorded as a function of excitation wavelength using a $300 \mathrm{~W}$ xenon lamp (ILC Technology, USA), which was focused through a Gemini-180 double monochromator (Jobin Yvon Ltd.). The incident photon-tocurrent conversion efficiencies (IPCEs) of the DSSCs constructed based on these dyes are shown in Figure 7(a). The monochromatic incident photon-to-collected electron conversion efficiencies of $60.71 \%$ and $75.89 \%$ were obtained for mLBD 1 and mLBD2 dyes, respectively, over the entire visible range extending into the NIR region, which are less than unity suggesting a low-charge collection yields. The photo current-voltage measurements were executed under air mass (AM) of 1.5 sunlight and the resultant $I-V$ curves are shown in Figure 7(b). The photovoltaic parameters of mLBD dyes are compared with that of black dye-sensitized solar 


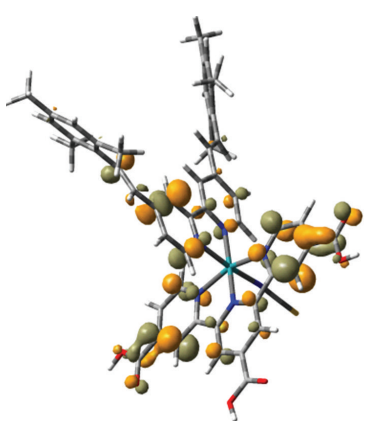

(a)

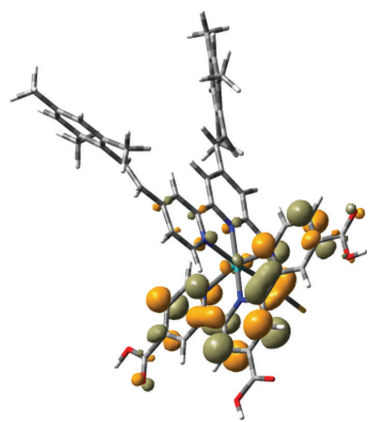

(d)

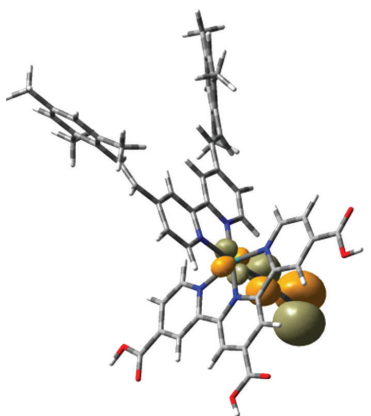

(g)

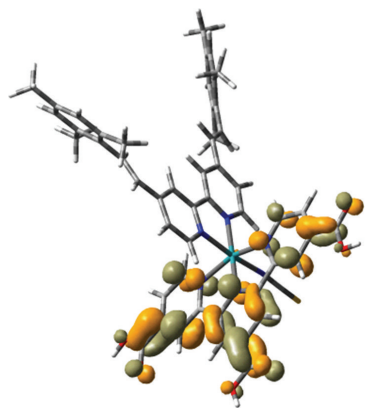

(b)

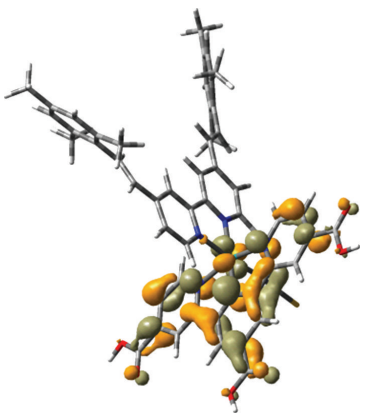

(e)

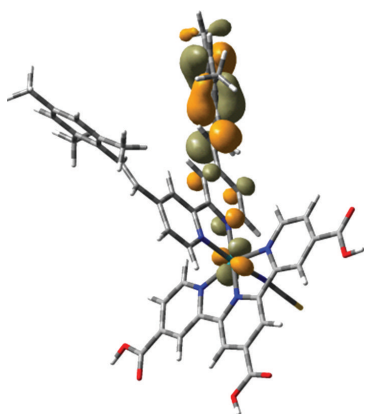

(h)

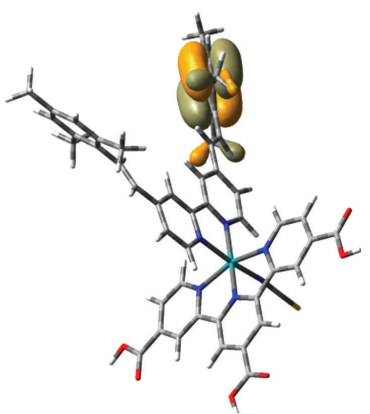

(j)

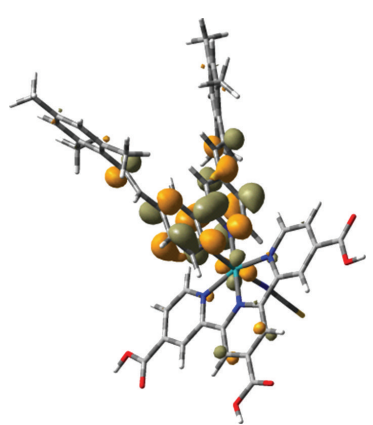

(c)

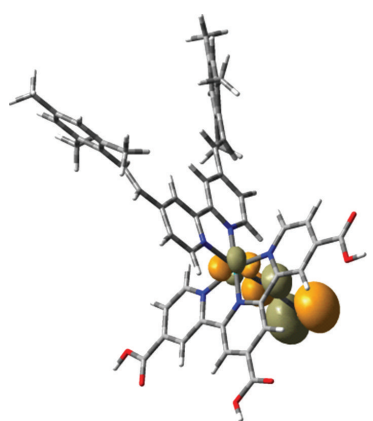

(f)

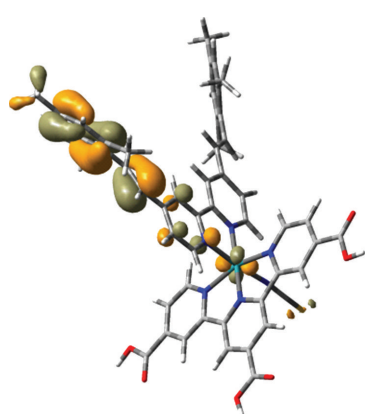

(i)

Figure 4: Frontier molecular orbitals of mLBD1: (a) LUMO+4; (b) LUMO+3; (c) LUMO+2; (d) LUMO+1; (e) LUMO; (f) HOMO; (g) $\mathrm{HOMO}-1$; (h) HOMO-2; (i) HOMO-3; (j) HOMO-4.

cell, fabricated, and evaluated under comparable conditions (Table 1).

The energy conversion efficiencies of $\mathrm{mLBD} 1$ and $\mathrm{mLBD} 2$ dyes are $3.15 \%\left(J_{\mathrm{SC}}=11.86 \mathrm{~mA} / \mathrm{cm}^{2}, V_{\mathrm{OC}}=613 \mathrm{mV}\right.$, $\mathrm{ff}=$ $0.4337)$ and $3.36 \%\left(J_{\mathrm{SC}}=12.71 \mathrm{~mA} / \mathrm{cm}^{2} ; V_{\mathrm{OC}}=655 \mathrm{mV}\right.$; $\mathrm{ff}=0.4042)$, respectively, under air mass of 1.5 sun light, the reference black-dye sensitized solar cell, fabricated, and evaluated under identical conditions exhibited $\eta$-value of $2.69 \%$ $\left(J_{\mathrm{SC}}=10.95 \mathrm{~mA} / \mathrm{cm}^{2}, V_{\mathrm{OC}}=655 \mathrm{mV}, \mathrm{ff}=0.3750\right) . \mathrm{Al}-$ though the film absorptions of $\mathrm{mLBD}$ dyes over $\mathrm{TiO}_{2}$ films are little lower as compared to that of black dye, the newly designed mLBD dyes were endowed with improved over 


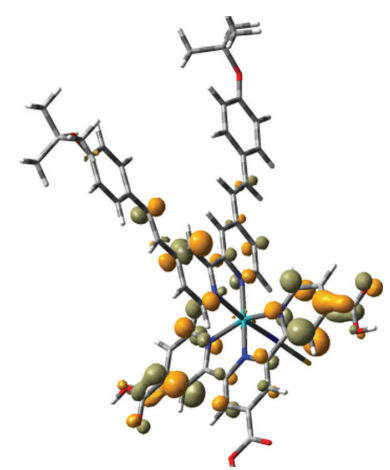

(a)

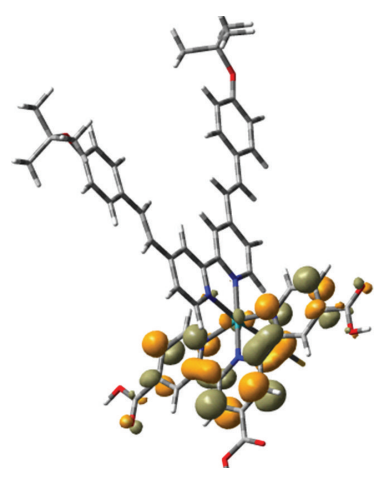

(d)

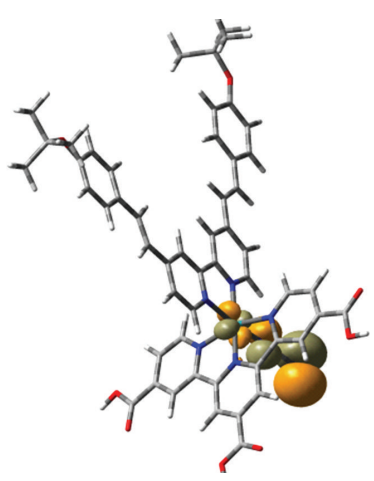

(g)

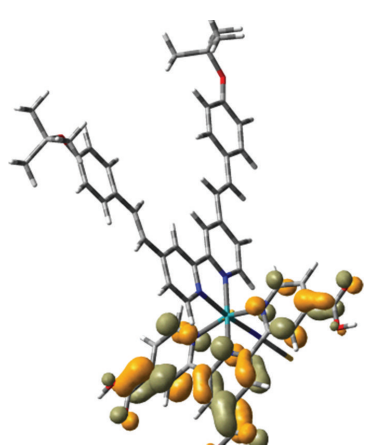

(b)

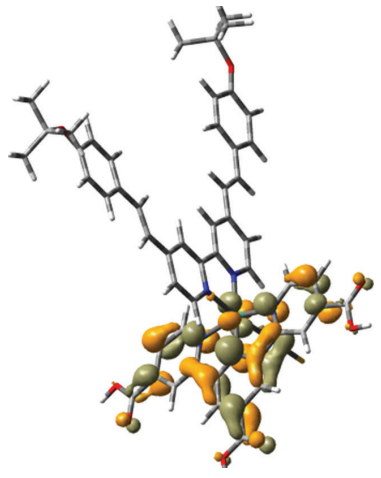

(e)

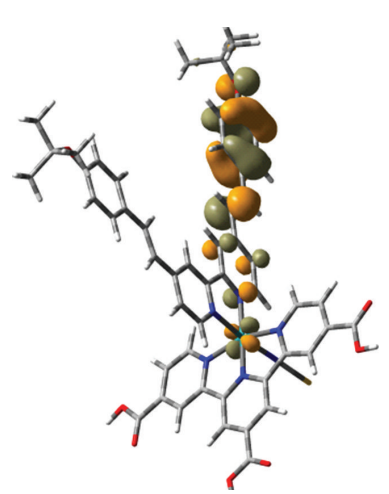

(h)

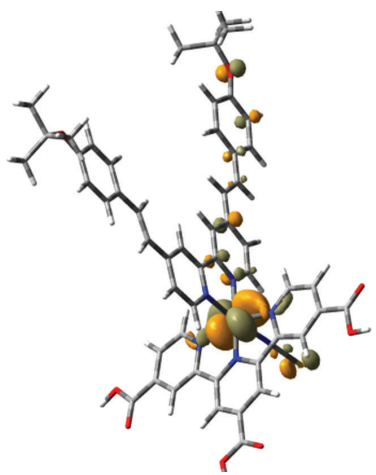

(j)

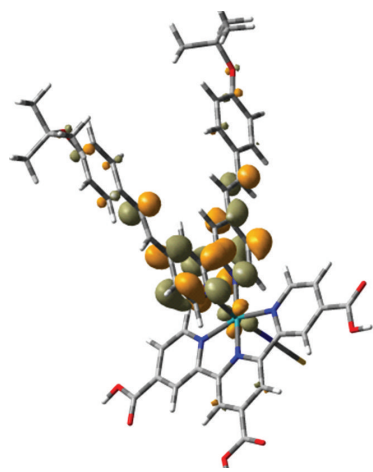

(c)

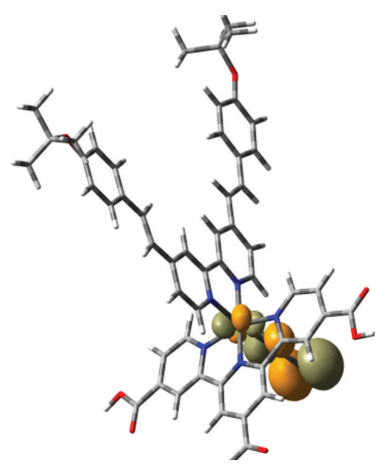

(f)

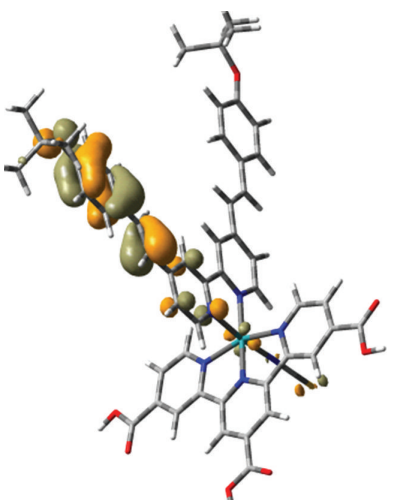

(i)

Figure 5: Frontier molecular orbitals of mLBD2: (a) LUMO+4; (b) LUMO+3; (c) LUMO+2; (d) LUMO+1; (e) LUMO; (f) HOMO; (g) HOMO-1; (h) HOMO-2; (i) HOMO-3; (j) HOMO-4. 
TABLE 1: Detailed photovoltaic parameters of DSSCs.

\begin{tabular}{lcccc}
\hline Sensitizer & $J_{\text {SC }}\left(\mathrm{mA} / \mathrm{cm}^{2}\right)$ & $V_{\text {OC }}(\mathrm{mV})$ & ff & Efficiency $(\%)$ \\
\hline mLBD1 & 11.86 & 613 & 0.4337 & 3.15 \\
mLBD2 & 12.71 & 655 & 0.4042 & 3.36 \\
BD & 10.95 & 655 & 0.3750 & 2.69 \\
\hline
\end{tabular}

Short-circuit photocurrent density (JSC), open-circuit photovoltage ( $\left.V_{\mathrm{OC}}\right)$, fill factor (ff).

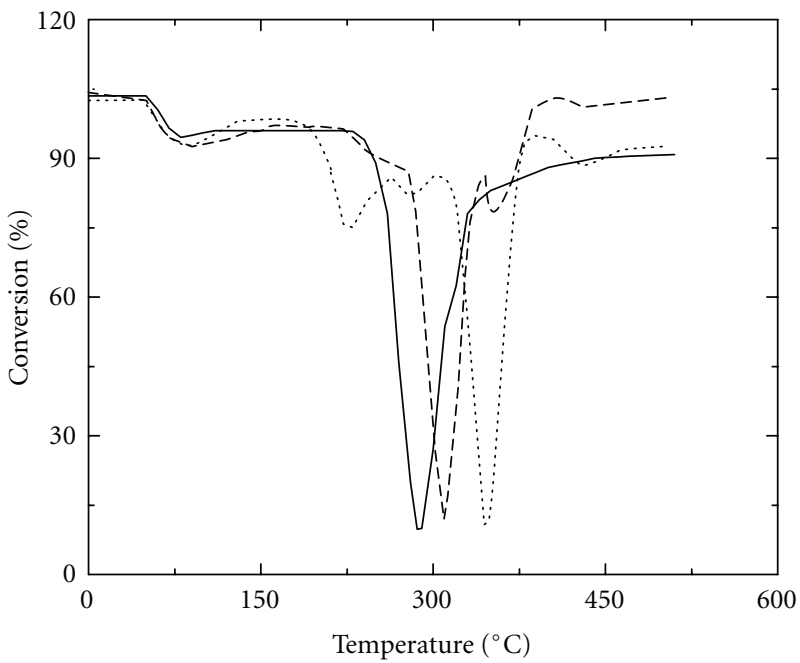

Figure 6: TG-Thermograms of mLBD1 (---), mLBD2 (..) and black-dye (-).

all conversion efficiencies. This could be probably due to more charge transfer to the LUMO orbitals for these dyes as compared to black dye. In the LUMO orbitals of these complexes, the electron density distributions mainly located on $\mathrm{H}_{3}$ tctpy ligand, while for black dye it is only ascribed to the centre pyridine of $\mathrm{H}_{3}$ tctpy [31]. As compared to the black dye-sensitized solar cell, the mLBD dyes showed higher current densities, which could be probably because of their increased incident photon to-current conversion efficiencies spectra. The mLBD2 sensitized solar cell gives $J_{\mathrm{SC}}=12.71 \mathrm{~mA} / \mathrm{cm}^{2}$, which is slightly higher as compared to that of mLBD1 sensitized solar cell. Although there is no much change in their film absorptions over $\mathrm{TiO}_{2}$ films, we presume that the increased photocurrent density and hence the efficiency of $\mathrm{mLBD} 2$ could be probably resulting from efficient dye regeneration mediated by redox electrolyte [32].

\section{Conclusions}

In conclusion, the new panchromatic ruthenium(II) terpyridyl-based mixed ligand dyes, mLBD1 and mLBD2 synthesized, showed much higher molar extinction coefficients at $400-550 \mathrm{~nm}$ remarkably with blue shift in absorption spectrum as compared to black-dye. Incorporation of conjugated light-absorbing ancillary bipyridine ligands into the new mixed ligand ruthenium(II) complexes provide a combined benefit of electron donor from ancillary conjugated

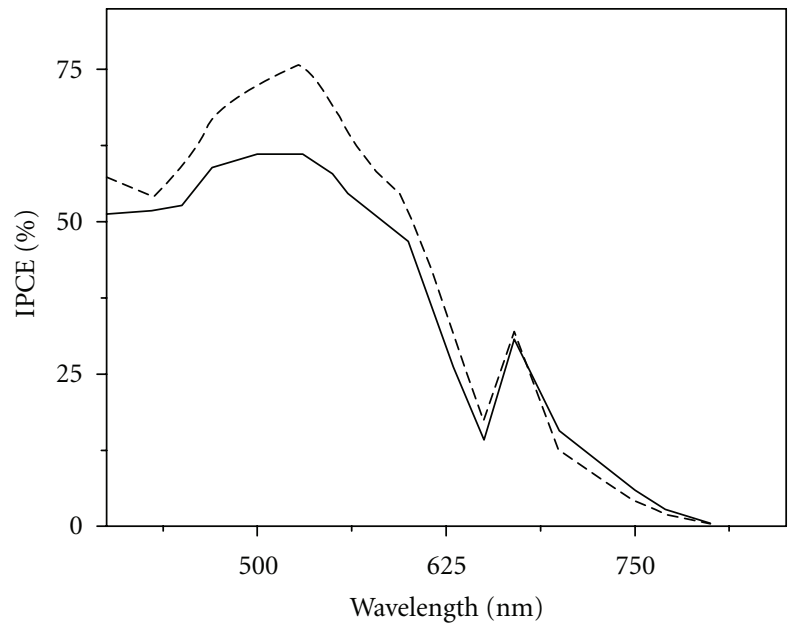

(a)

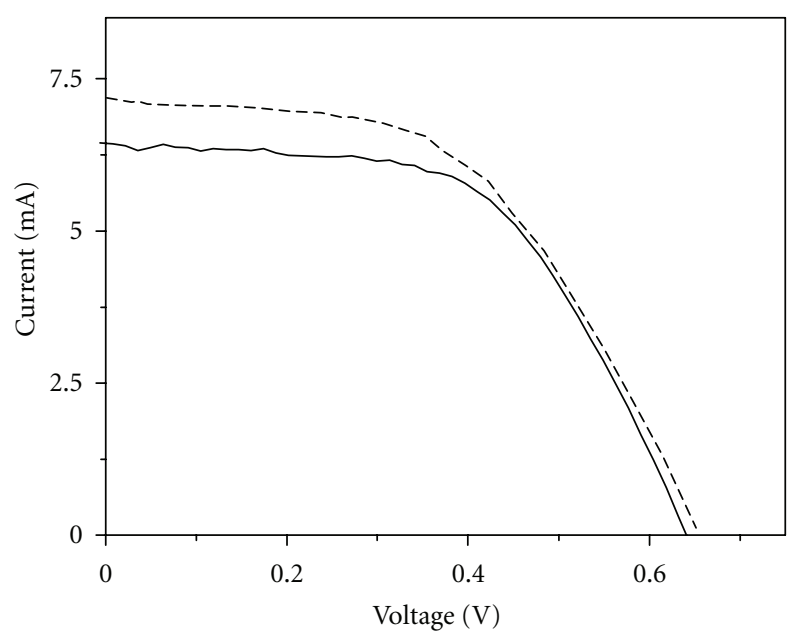

(b)

FIgUre 7: (a) Photocurrent action spectra of devices of mLBD1 (-) and mLBD2 (- - -) fabricated with Z580 electrolyte; (b) $J-V$ characteristics of mLBD1 (-) and mLBD2 (- - -) cells (fabricated from $0.74 \mathrm{~cm}^{2}$ active area $\mathrm{TiO}_{2}$ electrodes), measured under an irradiance of $100 \mathrm{~mW} \mathrm{~cm}^{-2}$ AM1.5G sun light. Double-layer films $(9.0+4.8 \mu \mathrm{m})$.

bipyridyl ligand as well as electron acceptor anchoring terpyridine tricarboxylic acid in the sensitiser to achieve better charge transfer from HOMO to LUMO. Though these ancillary bipyridines do not directly interfere with active sites of $\mathrm{TiO}_{2}$ electrode, the molecular diameter increased significantly and to some extent influenced the packing densities 
of the sensitizers over $\mathrm{TiO}_{2}$ films. These heteroleptic sensitizers exhibited better solar energy conversion efficiencies as compared to the standard black dye and mLBD2 sensitizer that showed an efficiency of 3.36\%, highest among the three.

\section{Acknowledgments}

Ch. S. Rao thanks IICT-AIC collaborative project for a fellowship. M. Chandrasekharam thanks DST, New Delhi, for the grant of the project entitled "Advancing the efficiency and production potential of Excitonic Solar Cells (APEX)" under UK-DST consortium.

\section{References}

[1] A. Hagfeldt, G. Boschloo, L. Sun, L. Kloo, and H. Pettersson, "Dye-sensitized solar cells," Chemical Reviews, vol. 110, no. 11, pp. 6595-6663, 2010.

[2] D. Wei, "Dye sensitized solar cells," International Journal of Molecular Sciences, vol. 11, no. 3, pp. 1103-1113, 2010.

[3] M. Grätzel, "Photoelectrochemical cells," Nature, vol. 414, no. 6861, pp. 338-344, 2001.

[4] B. O’Regan and M. Grätzel, "A low-cost, high-efficiency solar cell based on dye-sensitized colloidal $\mathrm{TiO}_{2}$ films," Nature, vol. 353, no. 6346, pp. 737-740, 1991.

[5] G. J. Meyer, "The 2010 millennium technology grand prize: dye-sensitized solar cells," ACS Nano, vol. 4, no. 8, pp. 43374343, 2010.

[6] S. M. Zakeeruddin, M. K. Nazeeruddin, R. Humphry-Baker et al., "Design, synthesis, and application of amphiphilic ruthenium polypyridyl photosensitizers in solar cells based on nanocrystalline $\mathrm{TiO}_{2}$ films," Langmuir, vol. 18, no. 3, pp. 952954, 2002.

[7] W. M. Campbell, A. K. Burrell, D. L. Officer, and K. W. Jolley, "Porphyrins as light harvesters in the dye-sensitised $\mathrm{TiO}_{2}$ solar cell," Coordination Chemistry Reviews, vol. 248, no. 13-14, pp. 1363-1379, 2004.

[8] P. Y. Reddy, L. Giribabu, C. Lyness et al., "Efficient sensitization of nanocrystalline $\mathrm{TiO}_{2}$ films by a near-IR-absorbing unsymmetrical zinc phthalocyanine," Angewandte Chemie, vol. 46, no. 3, pp. 373-376, 2007.

[9] D. Kuang, S. Uchida, R. Humphry-Baker, S. M. Zakeeruddin, and M. Grätzel, "Organic dye-sensitized ionic liquid based solar cells: remarkable enhancement in performance through molecular design of indoline sensitizers," Angewandte Chemie, vol. 47, no. 10, pp. 1923-1927, 2008.

[10] S. Tatay, S. A. Haque, B. O’Regan et al., "Kinetic competition in liquid electrolyte and solid-state cyanine dye sensitized solar cells," Journal of Materials Chemistry, vol. 17, no. 29, pp. 30373044, 2007.

[11] M. K. Nazeeruddin, F. D. Angelis, S. Fantacci et al., "Combined experimental and DFT-TDDFT computational study of photoelectrochemical cell ruthenium sensitizers," Journal of the American Chemical Society, vol. 127, no. 48, pp. 16835-16847, 2005.

[12] K. Hara, M. Kurashige, S. Ito et al., "Novel polyene dyes for highly efficient dye-sensitized solar cells," Chemical Communications, vol. 9, no. 2, pp. 252-253, 2003.

[13] M. Grätzel, "Solar energy conversion by dye-sensitized photovoltaic cells," Inorganic Chemistry, vol. 44, no. 20, pp. 68416851, 2005.
[14] C. Y. Chen, S. J. Wu, J. Y. Li, C. G. Wu, J. G. Chen, and K. C. Ho, "A new route to enhance the light-harvesting capability of ruthenium complexes for dye-sensitized solar cells," Advanced Materials, vol. 19, no. 22, pp. 3888-3891, 2007.

[15] M. K. Nazeeruddin, P. Péchy, T. Renouard et al., "Engineering of efficient panchromatic sensitizers for nanocrystalline $\mathrm{TiO}_{2}$ based solar cells," Journal of the American Chemical Society, vol. 123, no. 8, pp. 1613-1624, 2001.

[16] Z.-S. Wang, T. Yamaguchi, H. Sugihara, and H. Arakawa, "Significant efficiency improvement of the black dye-sensitized solar cell through protonation of $\mathrm{TiO}_{2}$ films," Langmuir, vol. 21, no. 10, pp. 4272-4276, 2005.

[17] L. Giribabu, C. V. Kumar, C. S. Rao et al., "High molar extinction coefficient amphiphilic ruthenium sensitizers for efficient and stable mesoscopic dye-sensitized solar cells," Energy and Environmental Science, vol. 2, no. 7, pp. 770-773, 2009.

[18] D. Kuang, C. Klein, S. Ito et al., "High effiiciency and stable mesoscopic dye-sensitized solar cells based on a high molar extinction cofficient Ru-sensitizer and non-volatile electrolyte," Advanced Materials, vol. 19, pp. 1133-1137, 2007.

[19] D. Kuang, C. Klein, Z. Zhang et al., "Stable, high-efficiency ionic-liquid-based mesoscopic dye-sensitized solar cells," Small, vol. 3, no. 12, pp. 2094-2102, 2007.

[20] M. Chandrasekharam, C. Srinivasarao, T. Suresh et al., "High spectral response heteroleptic ruthenium (II) complexes as sensitizers for dye sensitized solar cells," Journal of Chemical Sciences, vol. 123, no. 1, pp. 37-46, 2011.

[21] M. Chandrasekharam, G. Rajkumar, C. S. Rao et al., "Phenothiazine conjugated bipyridine-a new class of ancillary ligand for Ru-sensitizer in dye sensitized solar cell application," Synthetic Metals, vol. 161, pp. 1469-1476, 2011.

[22] M. Chandrasekharam, G. Rajkumar, C. S. Rao et al., "Polypyridyl $\mathrm{Ru}(\mathrm{II})$-sensitizers with extended $\pi$-system enhances the performance of dye sensitized solar cells," Synthetic Metals, vol. 161, no. 11-12, pp. 1098-1104, 2011.

[23] M. Chandrasekharam, G. Rajkumar, C. S. Rao, P. Y. Reddy, and M. L. Kantam, "Change of dye bath for sensitisation of nanocrystalline $\mathrm{TiO}_{2}$ films: enhances performance of dyesensitized solar cells," Advances in OptoElectronics, vol. 2011, Article ID 376369, 2011.

[24] L. Giribabu, M. Chandrasekheram, M. L. Kantham et al., "Conjugated organic dyes for dye-sensitized solar cells," Indian Journal of Chemistry A, vol. 45, no. 3, pp. 629-634, 2006.

[25] A. Islam, F. A. Chowdhury, Y. Chiba et al., "Synthesis and characterization of new efficient tricarboxyterpyridyl ( $\beta$ diketonato) ruthenium(II) sensitizers and their applications in dye-sensitized solar cells," Chemistry of Materials, vol. 18, no. 22, pp. 5178-5185, 2006.

[26] A. Mamo, A. Juris, G. Calogero, and S. Campagna, "Nearinfrared luminescence at room temperature of two new osmium(II) terdentate polypyridine complexes," Chemical Communications, no. 10, pp. 1225-1226, 1996.

[27] J.-J. Cid, J.-H. Yum, S.-R. Jang et al., "Molecular cosensitization for efficient panchromatic dye-sensitized solar cells," Angewandte Chemie International Edition, vol. 46, no. 44, pp. 8358-8362, 2007.

[28] Y. Chi and P.-T. Chou, "Contemporary progresses on neutral, highly emissive Os(ii) and Ru(ii) complexes," Chemical Society Reviews, vol. 36, no. 9, pp. 1421-1431, 2007.

[29] B. S. Chen, K. Chen, Y.-H. Hong et al., "Neutral, panchromatic $\mathrm{Ru}(\mathrm{ii})$ terpyridine sensitizers bearing pyridine pyrazolate chelates with superior DSSC performance," Chemical Communications, no. 39, pp. 5844-5846, 2009. 
[30] P. Wang, S. M. Zakeeruddin, J. E. Moser, M. K. Nazeeruddin, T. Sekiguchi, and M. Grätzel, "A stable quasi-solid-state dyesensitized solar cell with an amphiphilic ruthenium sensitizer and polymer gel electrolyte," Nature Materials, vol. 2, no. 6, pp. 402-407, 2003.

[31] M.-X. Li, H.-X. Zhang, X. Zhou, Q.-J. Pan, H.-G. Fu, and C.C. Sun, "Theoretical studies of the electronic structure and spectroscopic properties of $\left[\mathrm{Ru}(\text { Htcterpy })(\mathrm{NCS})_{3}\right]^{3-}$, , European Journal of Inorganic Chemistry, no. 15, pp. 2171-2180, 2007.

[32] D. Kuang, C. Klein, S. Ito et al., "High-Efficiency and stable mesoscopic dye-sensitized solar cells based on a high molar extinction coefficient ruthenium sensitizer and nonvolatile electrolyte," Advanced Materials, vol. 19, no. 8, pp. 1133-1137, 2007. 

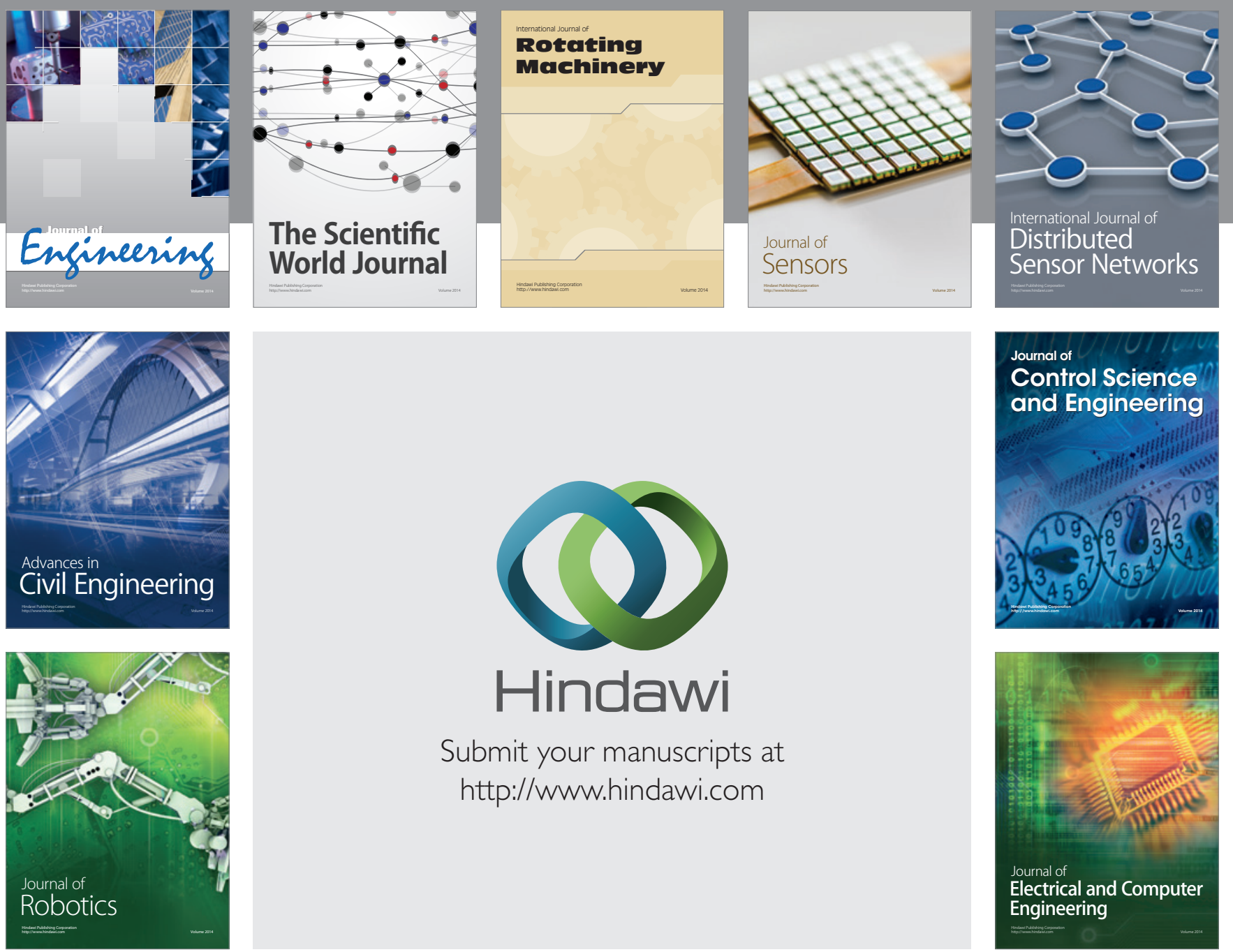

Submit your manuscripts at

http://www.hindawi.com
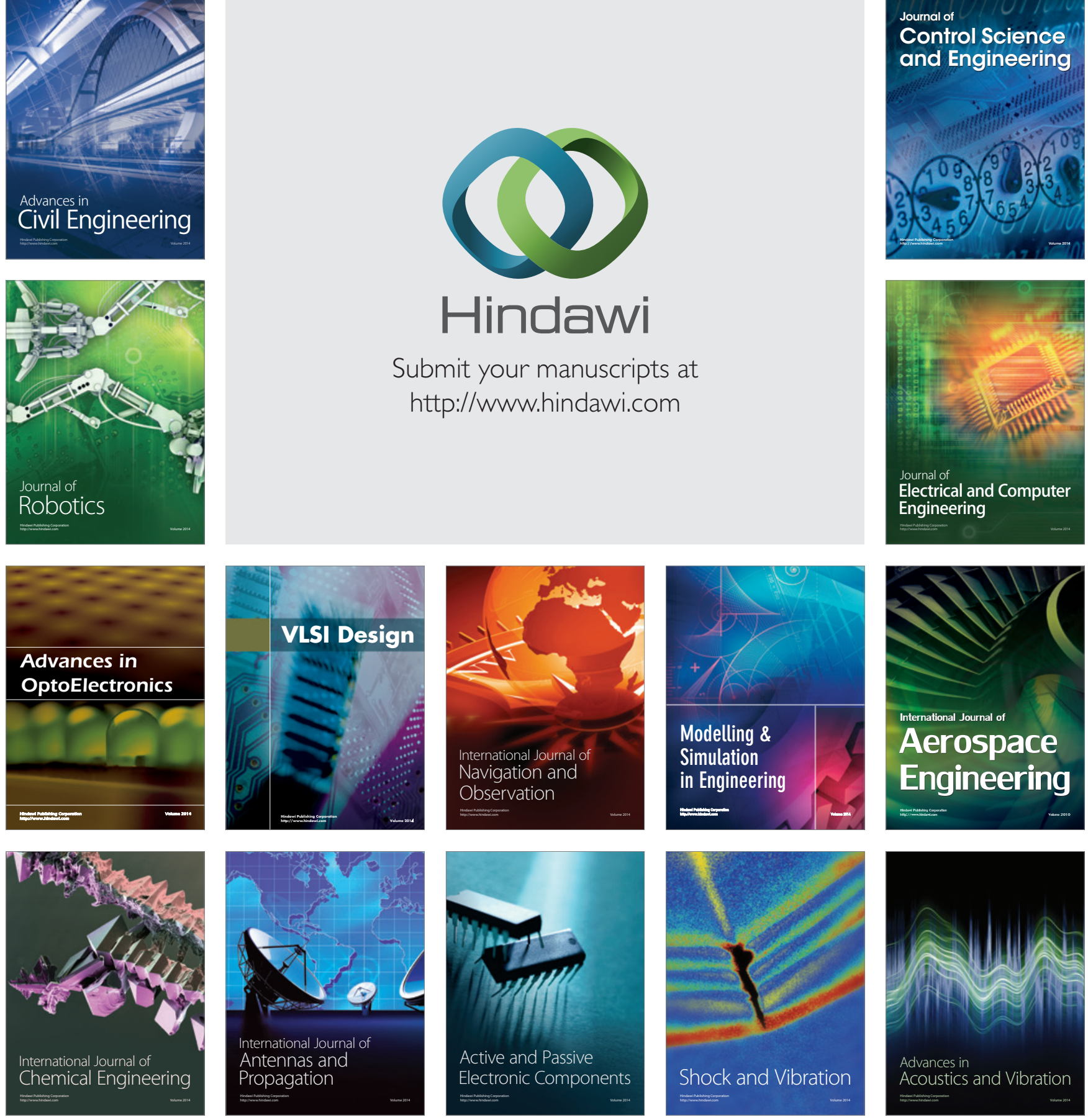